\title{
К ВОПРОСУ О ПРОТИВОДЕЙСТВИИ КОРРУПЦИИ В ПОЛИЦИИ
}

$\Pi$ роблема коррупции в различных направлениях деятельности органов государственной власти и управления приобрела в настоящее время глобальный и системный характер. Коррупция представляет сегодня непосредственную угрозу национальной безопасности, препятствует развитию в нашей стране институтов демократии и гражданского общества, препятствует реализации гражданами своих конституционных прав в сфере образования, здравоохранения, социального обеспечения, имущественных отношений. Кроме того, коррупция самым негативным образом сказывается на развитии экономики, а также финансовой системы и всей инфраструктуры российского государства в целом.

Коррупция в деятельности органов внутренних дел способствует развитию организованной преступности ${ }^{1}$, создает питательную почву для развития очагов экстремизма и терроризма, делает крайне затруднительными практически все государственно-правовые реформы, которые в настоящее время проводятся в нашей стране. Все эти и ряд других проблем делают объективно необходимым формирование административно-правового механизма противодействия корруп-

1 Не так давно происшедшие события в станице Кущевской Краснодарского края являются ярчайшим подтверждением того, как коррупция влияет на общественный порядок и режим личной безопасности граждан. ции в органах внутренних дел, как одного из важнейших правовых механизмов, которые сегодня могут и должны противостоять коррупции.

Растущая коррупция в органах внутренних дел (полиции), создала целый ряд проблем в деле обеспечения правопорядка, помимо всего прочего коррупция в ОВД снижает престиж государственного управления в Российской Федерации, как внутри страны, так и за рубежом. Коррупция, в том числе и коррупция в органах внутренних дел препятствует поступлению в экономику нашей страны иностранных инвестиций, стимулирует отток национального капитала за рубеж, создает угрозу правопорядку и безопасности государства. Коррумпированный государственный аппарат не способен противодействовать ни терроризму, ни экстремизму, ни организованной и экономической преступности. Исходя из вышеизложенного необходимо сделать вывод о том, что повышение эффективности административно-правовых и организационных средств противодействия в органах полиции представляется крайне актуальной проблемой.

Анализируя опыт специальных исследований в области противодействия коррупции ${ }^{2}$, представляет-

2 См.: Сафронов А.Д. Организационно-правовые аспекты предупреждения коррупции среди сотрудников органов внутренних дел. - М., 1993. - С. 18. 
ся возможным выделить целый ряд правонарушений, создающих условиях для возникновения коррупции в полицейской среде:

- использование своего статуса, а также основанных на нем авторитета и возможностей для вмешательства в деятельность других государственных и негосударственных органов;

- оказание не предусмотренного законодательством или необоснованного предпочтения физическим или юридическим лицам при подготовке и принятии решений по разного рода вопросам, входящих в компетенцию сотрудника ОВД;

- участие в качестве поверенных или представителей третьих лиц по делам органа, в котором данный сотрудник состоит на службе, либо по делам органов, подчиненных сотруднику, либо по делам органов, деятельность которых контролируются (или проверяется) сотрудниками ОВД.

- использование сотрудниками ОВД в личных или групповых интересах служебной и иной информации, полученной при выполнении служебных полномочий;

- нарушение установленного законами и иными нормативными правовыми актами порядка принятия и рассмотрения заявлений, жалоб, обращений физических и юридических лиц;

- необоснованный отказ физическим и юридическим лицам в информации, предоставление которой предусмотрено федеральными законами и иными нормативными правовыми актами, а также передача недостоверной или неполной информации или затягивание ее представления;

- требование от физических и юридических лиц информации, предоставление которой этими лицами не предусмотрено законами и иными нормативными правовыми актами;

- незаконное или необоснованное создание препятствий физическим и юридическим лицам в реализации их прав и законных интересов ${ }^{3}$.

Считаем возможным также выделить целый ряд факторов, провоцирующих коррупционные процессы в органах внутренних дел, а также иных исполнительных органах.

1. Правовой нигилизм значительной части сотрудников, циничное отношение к законам, которые они (сотрудники) призваны блюсти ${ }^{4}$.

3 См.: Сафронов А.Д. Организационно-правовые аспекты предупреждения коррупции среди сотрудников органов внутренних дел. - М., 1993. - С. 18.

4 См.: Железняк Н.С. О слагаемых коррупции в органах внутренних дел // Оперативник (сыщик). - 2008. - № 2. - С. 51.
2. Назначение на руководящие или «приносящие прибыль» должности по принципу личных связей, «личной преданности» вышестоящим начальникам или за денежное вознаграждение.

3. Возможность у сотрудника использования своего служебного положения и (или) должностных полномочий в корыстных целях, например неоправданно широкий спектр административного усмотрения.

Эффективное противодействие коррупции в органах полиции, возможно, на наш взгляд, посредством осуществления следующих мер:

- антикоррупционное образование и воспитание;

- антикоррупционная экспертиза проектов правовых актов МВД России;

- мониторинг коррупционных правонарушений и отдельных их видов;

- принятие в установленном законом порядке специальных требований к лицам, претендующим на занятие высоких должностей в системе МВД России;

- поощрение сотрудников за длительное и безупречное исполнение своих полномочий, честность и неподкупность, в том числе при решении вопросов представления к государственным наградам, почетным званиям, специальным званиям и иным знакам отличия;

- развитие института общественного и парламентского контроля за деятельностью органов внутренних дел, в том числе и на основе учета общественного мнения и оценки соответствующих материалов, имеющихся в распоряжении соответствующих общественных и парламентских комиссий (советов);

- создание механизма взаимодействия между правоохранительными органами и соответствующими общественными и парламентскими комиссиями (советами) по вопросам противодействия коррупции, с учетом невмешательства этих комиссий (советов) в исключительную компетенцию правоохранительных органов;

- формирование законодательной процедуры независимой оценки и расследования фактов и материалов о коррупционных правонарушениях (проступках) в случае конфликта интересов между компетентными органами, ранее проводившими по ним проверку или расследование.

Развитие в последние годы административноправовых средств противодействия коррупции в самих органах внутренних дел обусловлено в том числе и тем, что коррупция может иметь место в самых различных сферах правоохранительной деятельности. 
Коррупция может также проявляться при нарушении норм финансового, информационного и административного права. Представляется, что именно административно-правовые средства, в первую очередь, могут и должны(!) поставить барьер на пути возникновения и развития коррупции в органах внутренних дел, а также иных исполнительных органах государственной власти.

Коррупция в органах внутренних дел, а также иных исполнительных органах государственной власти носит социальный характер, имеет сложную структуру. В этой связи коррупция в органах полиции может рассматривается с экономической, политологической и правовой точки зрения. Такой подход позволит выявить различные формы коррупции, а также разработать современные средства борьбы с коррупцией в органах внутренних дел, дает возможность выявить связь полицейской коррупции с чиновничьей. Рассмотрев проблему зарождения и процветания коррупции в системе органов внутренних дел, мы можем еще раз, подытожив все вышесказанное, предложить следующие основные действия тактического характера, направленные на ослабление коррупционной угрозы в органах внутренних дел:
- активное внедрение (на разных уровнях) в сознание сотрудников органов внутренних дел идеологии неукоснительного соблюдения законов;

- повышение эффективности кадровой политики МВД, направленной на повышение уровня профессионализма;

- обеспечение «прозрачности» назначений на руководящие должности в МВД России и достижение хотя бы минимального уровня целесообразности с точки зрения интересов службы, таких назначений;

- честное и неукоснительное подавление протекционизма и фаворитизма, кумовства и т.д. в работе с кадрами органов внутренних дел (полиции);

- проведение мероприятий в системе МВД России, направленных на выработку позитивного отношения к службе, закрепление у сотрудника желания честно служить в органах внутренних дел РФ.

Все перечисленное органично связано между собой и только комплексное применение всех мер, ослабляющих разъедающее действие коррупции в органах внутренних дел, может в немалой степени исправить ситуацию, которая с каждым днем становиться все более угрожающей.

\section{Библиографический список:}

1. Горин Е.В., Костенников М.В., Куракин А.В. Актуальные проблемы административно-правового регулирования. - М., 2010.

2. Железняк Н.С. О слагаемых коррупции в органах внутренних дел // Оперативник (сыщик). — 2008. — № 2.

3. Колодкин Л.М. Использование зарубежного опыта профессиональной подготовки полицейских // Проблемы повышения качества профессиональной подготовки слушателей МВШМ МВД РФ. - М., 1992.

4. Куракин А.В. Государственная служба и коррупция. - М., 2009.

5. Костенников М.В., Куракин А.В. Административные запреты как средство противодействия коррупции в системе государственной службы. - М., 2010.

\section{References (transliteration):}

1. Gorin E.V., Kostennikov M.V., Kurakin A.V. Aktual'nye problemy administrativno-pravovogo regulirovaniya. M., 2010.

2. Zheleznyak N.S. O slagaemykh korruptsii v organakh vnutrennikh del // Operativnik (syshchik). — 2008. — № 2.

3. Kolodkin L.M. Ispol'zovanie zarubezhnogo opyta professional'noy podgotovki politseyskikh // Problemy povysheniya kachestva professional'noy podgotovki slushateley MVShM MVD RF. — M., 1992.

4. Kurakin A.V. Gosudarstvennaya sluzhba i korruptsiya. — M., 2009.

5. Kostennikov M.V., Kurakin A.V. Administrativnye zaprety kak sredstvo protivodeystviya korruptsii v sisteme gosudarstvennoy sluzhby. - M., 2010. 